\title{
Disinfection Processes and Mechanisms in Wastewater Stabilization Ponds: A Review
}

\begin{tabular}{|r|l|}
\hline Journal: & Environmental Reviews \\
\hline Manuscript ID & er-2018-0006.R1 \\
\hline Manuscript Type: & Review \\
\hline Aute Submitted by the & 23-Jul-2018 \\
\hline Complete List of Authors: & $\begin{array}{l}\text { Liu, Lei; Queens University, Civil Engineering } \\
\text { Hall, Geof; Queens University, Civil Engineering } \\
\text { Champagne, Pascale; Queens University }\end{array}$ \\
\hline Keyword: & $\begin{array}{l}\text { wastewater treatment, wastewater stabilization ponds, disinfection } \\
\text { mechanisms, environmental factors, indicator organisms }\end{array}$ \\
\hline &
\end{tabular}

\section{SCHOLARONE Manuscripts}


1 Disinfection Processes and Mechanisms in Wastewater Stabilization Ponds: A 2 Review

3 Lei Liu ${ }^{\mathrm{a}}$, Geof Hall ${ }^{\mathrm{a}}$ and Pascale Champagne

4 aDepartment of Civil Engineering, Queen's University, 58 University Ave., Kingston, ON K7L

53 N6, Canada

6 Corresponding author: Pascale Champagne (Email: pascale.champagne@queensu.ca; Tel.: +1-

$7 \quad 613-533-3053)$ 


\section{Abstract}

10 Wastewater stabilization ponds (WSPs) have been proven to be economical alternatives to

11 conventional wastewater treatment technologies due to their unique advantages, including ease

12 of operation, minimal energy input and minimal maintenance requirements. Their reported high

13 pathogen removal efficiencies have made WSPs a popular choice for wastewater treatment,

14 especially as tertiary lagoons. This paper provides a critical overview of the various disinfection

15 processes and mechanisms that occur in WSPs. A thorough review of the removal or attenuation

16 mechanisms for bacterial, viral, protozoan and helminthic pathogens is presented. Factors that

17 impact the removal efficiency of pathogenic organisms may include sunlight, $\mathrm{pH}$, dissolved

18 oxygen (DO), temperature, sedimentation, attachment, hydraulic retention time (HRT), pond

19 depth, predation and nutrient availability; the relationship between these factors is also discussed.

20 The purpose of this review paper is to utilize the current understanding of pathogen removal

21 mechanisms in pond systems to improve the operation and design of WSPs, and more

22 importantly, to provide guidance for the definition of regulations with respect to pathogen

23 removal in eco-engineered wastewater treatment systems such as WSPs.

25 Keywords: wastewater treatment, WSPs, disinfection mechanisms, environmental factors, 26 indicator organisms

\section{Introduction}

29 Wastewater management plays an important role in ensuring our future environmental 30 sustainability, especially with growing demands on water resources and the subsequent impacts

31 on receiving environments (Moumouni et al. 2016). Pressured by water scarcity and increases in 
32 water demand worldwide, treated wastewater has been reused for a variety of purposes over the

33 past few decades, such as for agricultural irrigation and other industrial, environmental and

34 municipal uses (Mo and Zhang 2012; Cornejo et al. 2013; Mosteo et al. 2013; Verbyla et al.

35 2016). The target 6.3 of the United Nations Sustainable Development Goals is to increase water 36 reuse globally by 2030 (United Nations 2015; Verblya et al. 2016). The potential for water reuse

37 is dependent on effective pathogen removal (Sharafi et al. 2015).

39 Passive or semi-passive systems, such as constructed wetlands and WSPs (Al-Hashimi and

40 Hussain 2013), are considered economical alternatives to conventional wastewater treatment

41 approaches. They are also known being effective in pathogen removal, so commonly applied as

42 tertiary treatment. In the United States and New Zealand, more than half of the wastewater

43 treatment facilities involve passive treatment systems (Mara 2003; US EPA 2011).

44 Approximately $90 \%$ of pond systems in the United States are used in small communities with

45 populations of less than 10,000 and have been shown to be very effective in treating wastewater

46 (Gray 2004). The removal of a wide spectrum of pathogenic microorganisms, such as bacterial,

47 viral, protozoan and helminthic pathogens, is commonly achieved in WSPs. Conversely, 48 disinfection methods (UV irradiation, chlorination and ozone) applied in conventional treatments

49 often only target pathogenic bacteria and viruses, as helminth eggs and protozoan (oo)cysts are

50 resistant to these disinfection methods (Jiménez 2007a; 2009; Drechsel et al. 2009). Some

51 studies have reported removals of up to $6 \log$ units of bacteria and practically all protozoan and

52 helminth eggs in WSP systems, producing final effluents that not only meet discharge to the

53 environment requirements in most jurisdiction, but also meet the WHO guidelines for the use of

54 treated wastewater in unrestricted agricultural irrigation (Bolton et al. 2010). The performance of 
55 WSP systems has been reported to be superior to that of conventional treatment processes, such

56 as activated sludge or primary treatments, for which reductions of 1 to $2 \log$ units for bacteria

57 and 70-99\% for protozoan and helminth eggs have been noted (Ansa et al. 2012).

59 This paper provides a review of the operational conditions and mechanisms contributing to

60 disinfection in WPS systems. Physical, chemical and biological parameters that impact the

61 efficiency of pathogen removal are characterized and discussed. In addition, consideration is

62 given to alternative indicators and their potential benefits in the context of public and

63 environmental safety. Moreover, the information summarized herein can be used to assess

64 microbial risk in treated wastewater in order to develop wastewater discharge guidelines and

65 regulations, as well as safe water reuse policies.

\section{Pathogen removal in WSPs}

67 There are three different pathways by which pathogenic microorganisms can enter a WSP:

68 influent wastewater, regrowth with the WSPs and animal activities. There are approximately 60

69 known types of waterborne human pathogens (Wu et al. 2016) and it would be very cost-

70 intensive to assess each of them in a timely manner in the effluent of a WSP. Therefore, treated

71 wastewater is routinely assessed through the monitoring of bacterial indicator organisms

72 (typically E. coli, FC or TC). In addition, turbidity and total suspended solids (TSS) are often

73 used to indicate the potential presence of pathogenic microorganisms, as these parameters that

74 have been demonstrated to be correlated with the presence of pathogens (Rose et al. 2004).

75 Although WSPs are considered to be a relatively well-established biological method for the

76 removal of pathogens, there remains some knowledge gaps regarding the importance of

77 mechanisms such as sunlight, $\mathrm{pH}, \mathrm{DO}$ and other environmental factors by which pathogens could 
78 be effectively removed (Reinoso et al. 2011; Mosteo et al. 2013). Removal efficiencies of

79 pathogenic and indicator microorganisms during wastewater treatment can be inconsistent and

80 have been shown to vary, depending on the type of treatment process, as a function of HRT,

81 solids retention time (SRT), sunlight, DO concentration, $\mathrm{pH}$, temperature and the efficacy in TSS

82 removal (Tyagi et al. 2011). Generally, an optimally functioning eco-engineered system could be

83 expected to achieve $90-99 \%$ microbial reductions, but in some cases, poor reductions have been

84 observed and treated effluents could contain high numbers of fecal microorganisms (George et

85 al. 2002; Koivunen et al. 2003; Reinoso et al. 2008).

86

87 Table 1-4 summarize the log/percentage removal of bacteria, viruses, protozoa and helminthes

88 from WSP systems operating world-wide. It shows a wide variation in performance, as pathogen

89 removal in WSPs can be location and climate specific. Hence, disinfection efficiency can be

90 influenced greatly by environmental conditions as well as different disinfection mechanisms

91 factor. 


\section{Factors affecting pathogen removal in WSPs}

93 WSPs have generally been shown to be effective in the reduction or removal of pathogens.

94 Reinoso et al. (2011) reported that Cryptosporidium oocysts could effectively be reduced by an

95 average of $96 \%$, Giardia cysts by $98 \%$ and helminth eggs by $100 \%$ in a Spanish pond system

96 consisting of two anaerobic ponds running in parallel, a facultative pond followed by a

97 maturation pond operated under both winter and summer season operations (from December

982003 to September 2004). In other studies world-wide, WSPs have been reported to remove up

99 to $7 \log$ units of bacteria, up to $5 \log$ units of viruses and almost $100 \%$ helminth ova (Zanotelli et

100 al. 2002; Awuah 2006; Jimenez 2007c; Tyagi et al. 2011; Reinonso et al. 2011; Liu et al., 2018).

101

102 A number of studies have attempted to explain the factors responsible for pathogen reduction in

103 passive wastewater treatment systems. As shown in Figure 1, pathogen removal within WSPs is

104 considered to be a complex process involving various physical, chemical and biological factors, 105 alone or in combination, including sunlight, $\mathrm{pH}, \mathrm{DO}$, temperature, predation, 106 attachment/sedimentation and starvation (Maynard et al. 1999; Awuah et al. 2001; Oilgae 2009; 107 Fisher et al. 2012).

108

109 Sunlight

110 Sunlight has a lethal impact on coliform bacteria and the die-off rate has been reported to be

111 proportional to sunlight intensity (Curtis et al. 1992a; 1994; Kadir and Nelson 2014; Champagne

112 et al. 2017). As shown in Figure 2, different wavelength regions of the solar spectrum, such as

113 the ultraviolet (UV) spectrum (290-400nm) and photosynthetically active radiation (PAR) (400-

$114700 \mathrm{~nm}$ ), have been shown to contribute differently to disinfection in wastewater (Bolton 2010). 
115 Sunlight damage in pond systems has been attributed to three mechanisms: direct damage to

116 DNA by UV-B wavelengths (280-320nm); indirect endogenous (part of the virion) damage

117 caused by UV-B; and indirect exogenous (in solution) damage involving UV-A (320 - $400 \mathrm{~nm}$ ),

118 UV-B and PAR (Davies- Colley et al. 1999; 2000; Kadir and Nelson 2014).

120 Studies by Sarikaya and Saatci (1987) and Mayo (1989) each indicated that using light alone 121 might not achieve significant FC removals. In a more recent study, Kadir and Nelson (2014) also 122 found that direct damage by UV-B light was not a significant removal mechanism for E. coli and 123 E. faecalis. These findings suggest that indirect endogenous and exogenous photo-oxidation may 124 play a more important role in sunlight-mediated inactivation of pathogens. Photo-oxidation is the 125 process by which photo-sensitizers absorb light and transfer its energy to other molecules, 126 leading to the formation of reactive oxygen species (ROS). ROS react with membranes of 127 microorganisms and consequently cause damage. Photo-oxidation occurs when ROSs are 128 produced by endogenous and exogenous photo-sensitizers as well as by other reactions, such as 129 Fenton's reaction (Curtis et al. 1992b; Kohn and Nelson 2007; Bolton 2010). Endogenous photo130 sensitizers, such as flavins and porphyrin derivatives, are found inside the cell of microbes, while 131 exogenous photo-sensitizers, such as humic substances, photosynthetic pigments and dissolved 132 organic matter (DOM), are present outside the cell in the aquatic environment (Curtis et al. 133 1992b; Kohn and Nelson 2007).

135 Sunlight, however, is attenuated with depth as it penetrates into the water column. In particular, 136 shorter wavelengths, such as UV, may be only effective at pond surfaces (Curtis et al. 1994; 137 Kadir and Nelson 2014; Verbyla and Mihelcic 2015). This may explain the limited effect of UV- 
138 B in directly damaging DNA. Conversely, longer wavelengths (PAR spectrum) can penetrate

139 much deeper into the water column, hence their effect can potentially be more important for 140 disinfection (Kadir and Nelson 2014). Kohn and Nelson (2007) reported that more than 99\% of 141 UV-B light at $290 \mathrm{~nm}$ was absorbed in the first $2.5 \mathrm{~cm}$ depth of a WSP, while over $99 \%$ of 142 visible light at $556 \mathrm{~nm}$ was absorbed in the first $8 \mathrm{~cm}$. Sunlight gets attenuated more readily in 143 turbid water due to the higher solids and/or microbial and/or organic matter concentrations.

145 The response of different bacteria to sunlight damage can vary considerably. In studies by 146 Mezrioui et al. (1995a, 1995b), it was observed that sunlight had a much greater effect on E. coli 147 survival than on $V$. cholerae as the concentration of E. coli was markedly reduced, particularly 148 during the warmer seasons in a WSP operating in Marrakesh, Morocco. Many studies have 149 focused on the sunlight mechanisms contributing to bacterial pathogen removal, including both 150 endogenous and exogenous bacterial inactivation (Berney et al. 2006a; Berney et al. 2006b; 151 Bosshard et al. 2010a; Bosshard et al. 2010b; Fisher et al. 2012; Santos et al. 2012; Sassoubre et 152 al. 2012; Kadir and Nelson, 2014). Kadir and Nelson (2014) concluded that the inactivation of $E$. 153 coli occurs through endogenous mechanisms promoted by UV-B and UV-A, while the 154 inactivation of E. faecalis is mainly through exogenous mechanisms facilitated by UV-A and 155 visible wavelengths. Different exogenous photo-sensitizers, such as humic substances, may also 156 induce various degrees of photo-oxidation (Curtis et al. 1992b, MacDougall 2016).

159 biocides are generally well understood, virus inactivation mechanisms are often contradictory. 160 Photo-sensitizers assist with bacterial inactivation through photo-oxidation; however, they may 161 not have a similar effect on viruses as they lack a bound chromosphere to act as the endogenous 
162 photo-sensitizer (Kohn and Nelson, 2007). Hence, a detailed mechanistic understanding does not

163 yet exist for viruses. The development of a thorough understanding of virus inactivation is

164 complicated by the fact that related viruses can often exhibit different disinfection kinetics when

165 treated with the same disinfectant under similar conditions (Baxter et al. 2007; Cromeans et al.

166 2010). These different responses suggest that even minor variations in structural or genomic

167 components can have a marked impact on viral resistance to inactivation. It has been

168 demonstrated that exposure to inactivating oxidants and radiation can result in modifications to

169 viral proteins (Sano et al. 2009; Hotze et al. 2009; Wigginton et al. 2010) and nucleic acids

170 (Nuanualsuwan et al. 2002; Li et al. 2004), leading to inactivation of viruses.

172 Sunlight-mediated inactivation may not be the most effective route to protozoan and helminthic

173 disinfection. Reinoso et al. (2011) demonstrated that sunlight exposure increased the rate of

174 Cryptosporidium parvum (C. parvum) oocyst inactivation compared to dark conditions, reaching

175 a maximum difference of $40 \%$ after 4 days of exposure. While UV radiation is widely used for

176 water disinfection, its efficacy against FLA has not been widely reported when compared to

177 other protozoa such as C. parvum. Hijnen et al. (2006) provides a comprehensive overview on

178 the role of UV radiation in cysts inactivation and reported that Acanthamoeba spp. is highly UV

179 resistant. Acanthamoeba spp. cysts were demonstrated to be resistant to exposure to UV-C at

$180253.7 \mathrm{~nm}$ at $1.1 \mathrm{~mJ} \mathrm{~s}^{-1} \mathrm{~cm}^{-2}$ (Hwang et al. 2004), while Acanthamoeba castellanii (A. castellanii)

181 cysts were shown to be resistant to UV-B irradiation at $800 \mathrm{~mJ} \mathrm{~cm}^{-2}$ and Balamuthis mandrillaris

182 (B. mandrillaris) cysts to exposure at $200 \mathrm{~mJ} \mathrm{~cm}^{-2} \mathrm{UV}$ irradiation (Siddiqui and Khan 2008).

183 Another study reported a $4 \log$ reduction of Acanthamoeba polyphaga (A. polyphaga) cysts after

184 exposure to $40 \mathrm{~mJ} \mathrm{~cm}^{-2}$ (Loret et al. 2008). Exposure of $A$. polyphaga cysts to simulated global

185 solar irradiance in water $\left(85 \mathrm{~mJ} \mathrm{~s}^{-1} \mathrm{~cm}^{-2}\right)$ did not achieve cyst inactivation when the temperature 
186 was maintained $<40^{\circ} \mathrm{C}$, but yielded better results at $45^{\circ} \mathrm{C}\left(1.2 \log _{10}\right.$ reduction after $\left.6 \mathrm{~h}\right), 50^{\circ} \mathrm{C}(>$

$1873.6 \log _{10}$ reduction after $\left.6 \mathrm{~h}\right)$ and $55^{\circ} \mathrm{C}\left(>3.3 \log _{10}\right.$ reduction after $\left.4 \mathrm{~h}\right)$ (Heaselgrave et al. 2006).

188 Sixty one percent of Naegleriagruberi cysts were still alive after UV irradiation with $21.6 \mathrm{~mJ}$

$189 \mathrm{~cm}^{-2}$, but treating amoebae with DNA repair mechanism inhibitors was noted to improve UV

190 irradiation efficacy (Hillebrandt and Muller 1991). Similarly, photo-sensitized inactivation of

191 Acanthamoeba palestinensis in the cystic stage has also been demonstrated by incubating cysts

192 with tetracationic $\mathrm{Zn}$ (II)-phthalocyanine prior to exposure to 600-700 $\mathrm{nm}$ wavelength light

193 sources (Ferro et al. 2006). Protozoa in cyst or oocyst form are generally considered resistant to

194 UV irradiation, but there are likely differences in UV sensitivity depending on the strain or

195 species. UV mechanisms could be more effective in protozoa inactivation with the application of

196 longer exposures (days) or other operational factors, such as higher temperatures. Very few

197 studies have examined the effects of visible wavelengths or photo-oxidation in protozoa 198 inactivation.

$201 \mathrm{pH}$ plays an important role in pathogen removal in WSPs, and can be highly influenced by the 202 presence of algae in the system (Wallace et al. 2016; Champagne et al. 2017). Photosynthesis is 203 the process by which light energy is transformed into chemical energy by the chloroplast in 204 autotrophs. In general, this process converts carbon dioxide and water into organic molecules. As 205 shown in Figure 3, in aquatic photosynthesis, algae uptake $\mathrm{CO}_{2}$ and release $\mathrm{O}_{2}$, leading to an 206 increase in $\mathrm{pH}$ and DO concentration (Fallowfield et al. 1996). Therefore, high pH levels are 207 often observed in WSPs, with values frequently varying diurnally within a range of $7-9.4$ 208 (Curtis et al. 1992a; Sweeney et al. 2007; Bolton et al. 2010; Wallace et al. 2016). Neutral to 
209 slightly acidic pH conditions (between 6.5 and 7.5) have been reported as optimal for fecal

210 bacteria growth (Awuah 2006), while $\mathrm{pH}$ levels higher than 8.5 have been noted to be effective

211 for the removal of indicator organisms (Davies-Colley et al. 1999; 2000; Awuah et al. 2002;

212 Ansa et al. 2011; 2012; Liu et al. 2015). Fluctuations in $\mathrm{pH}$ have been shown to negatively affect

213 the survival of E. coli (Awuah 2006).

214

215 Some bacteria behave differently under different $\mathrm{pH}$ conditions. David-Colley et al. (1999) found

216 that the inactivation rate of E. coli increased when $\mathrm{pH}$ was above 8.5. Enterococci were found to

217 be more tolerant to high $\mathrm{pH}(>9)$ than to acidic conditions (Awuah et al. 2001). Inactivation of $E$.

218 coli increased with increasing $\mathrm{pH}$ while in contrast, Enterococci was noted to exhibit similar

219 rates of inactivation at all pH levels (Davies Colley et al. 1999; Nelson et al. 2009; Ouali et al.

220 2014). In a study by Mezrioui et al. (1995a), it was found that $\mathrm{pH}$ of 8 and 8.8 (tested $\mathrm{pH}$ include

$2216.6,7.3,8$ and 8.8) inhibited the survival of $E$. coli and prolonged the survival of $V$. cholera. The

222 contrast in the behavior of these organisms in response to their exposure to elevated $\mathrm{pH}$ levels

223 could be due to a different reaction mechanisms or sensitivity to sunlight (Maynard et al. 1999;

224 Kadir and Nelson 2014), where damage to the cytoplasmic membranes of bacteria caused by 225 sunlight could render the organisms more vulnerable to the effects of other factors such as high $226 \mathrm{pH}$ (Curtis et al. 1992a). In their study on WSPs, Davies-Colley et al. (1999) reported that 227 Enterococci were immune to sunlight when $\mathrm{pH}$ was increased from 7.5 to 9.5 and under low DO 228 levels. However, a number of studies have demonstrated that light-induced inactivation of E. coli 229 was dependent on pH (Davies-Colley et al. 1997; 1999; Ouali et al. 2014). Under moderate pH 230 conditions, E. coli was inactivated by endogenous photo-sensitizers, but when the $\mathrm{pH}$ was raised 231 to above 8.5, E. coli was inactivated more rapidly by exogenous mechanism (Davies-Colley et al. 232 1997; 1999). 
234 Information on the manner in which $\mathrm{pH}$ inactivation impacts viruses, protozoa and helminthes is 235 limited. Viral attachment was observed to be a function of water $\mathrm{pH}$ in ground water studies 236 (Bales et al. 1993; 1997; Guan et al. 2003). It was shown that pH levels above 12 could 237 inactivate helminth ova (Jimenez 2007c). However, pH levels above 12 may not be desirable in 238 most WSP environments, particularly when these systems discharge into receiving environments.

239 There is much debate in the literature on whether sunlight or $\mathrm{pH}$ is the most important 240 mechanism for pathogen removal, and there are conflicting results on the contribution of these 241 two mechanisms as previously discussed, hence, more targeted and systematic research is 242 required in this area.

\section{DO}

245 Oxygen concentrations above $0.5 \mathrm{mgL}^{-1}$ have been shown to contribute to the removal of fecal 246 bacteria (Van Buuren and Hobma 1991; Ansa et al. 2011). As previously noted, oxygen is 247 produced as a by-product of algal photosynthesis, which is a source of oxygen supply in WSPs. 248 Sweeney et al. (2007) observed DO concentration as high as $30 \mathrm{mg} / \mathrm{L}$ in a single pond system at 249 the Bolivar Wastewater Treatment Plant in Adelaide, South Australia during the summer period. 250 Photo-oxidation requires the presence of oxygen to form ROC, therefore, an increase in DO 251 concentration would likely increase the effect of photo-oxidation. As an example, the light 252 inactivation of $E$. coli and Enterococci has been reported to increase with increasing DO 253 concentrations (Curtis et al. 1992a; David-Colley et al. 1994; Ouali et al. 2014). David-Colly et 254 al. (1994) found that the inactivation rates of Enterococci increased significantly with increasing 255 DO levels when $\mathrm{pH}$ and light intensity remained constant. In their study, David-Colley et al. 
256 (1994) also observed a synergistic increase in inactivation of $E$. coli when both DO and $\mathrm{pH}$

257 increased. This may imply that endogenous photo-inactivation of E. coli and Enterococci were

258 strongly dependent on DO (Davies Colley et al. 1999; Ouali et al. 2014).

260 As facultative anaerobes, FC are able to survive over a wide range of oxygen concentrations.

261 However, under anaerobic conditions, FC were found to survive for longer periods than under 262 aerobic conditions (Klock 1971). In their separate studies Klock (1971) and Marais (1974) found 263 that aeration enhanced FC die-off rates. Kaneko (1997) also observed that the removal of 264 polioviruses, bacteriphages and Coxsackie virus B3 was enhanced by aeration. Davies-Colley et 265 al. (1999) noted that the inactivation of the F-DNA virus was independent of DO concentration, 266 while the inactivation of the F-RNA virus increased with increasing DO concentrations (Awuah 267 2006). To date, there has been very little information regarding the effect of DO concentration on 268 protozoa and helminth egg removal and/or inactivation.

270 Indicator microorganisms respond differently to $\mathrm{pH}$, water temperature and DO levels (Love et al. 271 2010; Ouali et al. 2014; Champagne et al. 2017). Bolton et al. (2011) reported that the effect of 272 DO concentration on inactivation rates was organism-dependent. Significant correlations 273 between kinetic disinfection coefficient $(\mathrm{K})$ and $\mathrm{pH}, \mathrm{DO}$, temperature and light intensity were 274 observed. The kinetic coefficient (K) values for E. coli and Enterococci were found to be 275 dependent on physicochemical parameters $(\mathrm{pH}, \mathrm{DO}$, water temperature and light intensity), 276 where $\mathrm{K}$ has generally been reported to increase with increasing $\mathrm{pH}$, light intensity and 277 temperature (Ouali et al. 2014). 


\section{Temperature}

280 Although optimal rates of bacterial growth are typically restricted to small temperature ranges, 281 bacterial organisms are able to survive within broader temperature limits. Some researchers have 282 stated that the minimum water temperature required for the treatment of wastewater using WSPs 283 is $7^{\circ} \mathrm{C}$ with higher temperatures stimulating bacterial growth, where growth rates doubles with 284 approximately every $10^{\circ} \mathrm{C}$ increase in temperature until optimal growth is reached (USEPA 1983; 285 Metcalf and Eddy 2003). Several researchers have reported increased removal efficiencies of FC 286 at higher temperatures (Polprasert et al. 1983; Pearson et al. 1987a;b; Barzily and Kott 1991;

287 Ouali et al. 2014; Champagne et al. 2017). In a study by Mezrioui et al. (1995b), fecal coliforms 288 were reduced by $98.95 \%$ during the warmer seasons and by $94.91 \%$ during the cold seasons in a 289 WSP system, operating in Marrakesh, Morocco. This system consisted of an anaerobic and an 290 aerobic pond in series. They also found that when temperature was increased from $8^{\circ} \mathrm{C}$ to $23^{\circ} \mathrm{C}$, 291 the removal rate of $E$. coli also increased.

293 It has been noted that bacterial removal with increasing temperature in horizontal flow 294 constructed wetlands (CWs) (Winward et al. 2008). In a study by Boutiler et al. (2009), the first 295 order rate constants for E. coli removal were 0.09 day $^{-1}$ at $7.6{ }^{\circ} \mathrm{C}$ and 0.18 day ${ }^{-1}$ at $22.8{ }^{\circ} \mathrm{C}$ in a 296 laboratory experiment using domestic wastewater collected from a surface flow wetland. Ulrich 297 et al. (2005) reported that higher temperatures improved the removal of bacterial indicator 298 organisms by $1 \log (\mathrm{CFU} / 100 \mathrm{~mL})$, when comparing the operation of a $\mathrm{CW}$ in summer and winter 299 seasons. Jokerst et al. (2011) found that the wetland was able to remove an average of $1.7 \log$ $300 \mathrm{CFU} / 100 \mathrm{~mL}$ E. coli in spring, summer and fall, but an average of $1.0 \log \mathrm{CFU} / 100 \mathrm{~mL}$ in winter. 
302 Different bacteria have been reported to respond differently to temperature change. Mezrioui et 303 al. (1995a) found that $V$. cholera did not survive as well as $E$. coli at a temperature of $8^{\circ} \mathrm{C}$, and a 304 Spearman correlation between temperature and the concentrations of $V$. cholera in a WSP in the 305 arid region of Marrakesh, Morocco was 0.91. Conversely, Mara and Pearson (1986) concluded 306 that there was no direct relationship between FC die-off and temperature and that a tertiary pond 307 exhibited higher levels of FC removal than anaerobic and facultative ponds when operated at the 308 same temperature. Factors, other than temperature, may have contributed to the higher removal 309 efficiencies observed in this case. This supports the theory that pathogen removal in WSP is 310 driven by several mechanisms and operational factors. However, to date, temperature effects on 311 viral, protozoan and helminthic pathogens have not been investigated extensively.

\section{Attachment \& Sedimentation}

314 Sedimentation has been reported to be effective in removing some microorganisms, such as

315 helminth eggs as they have a higher settling velocities $(\sim 0.1 \mathrm{~mm} / \mathrm{s}$ ) (Sengupta et al. 2011, Wu et 316 al. 2016). However, bacteria, viruses and protozoa have much lower settling velocities, so they 317 can be remove through sedimentation only if they attach to larger particles (Jasper et al. 2013).

319 In a study by Ansa et al. (2012), investigating the attachment of FC in pond systems, FC 320 attachment to suspended matter was determined to significantly contribute to FC removal only in 321 the first two maturation ponds $(71 \%$ - 99\% removal efficiencies), and was generally more 322 pronounced at the bottom of the ponds. Mahler et al. (2000) observed that a significant 323 proportion of bacteria were associated with suspended solids in wastewater. Bacteria in the 324 aqueous media attach to solid surfaces by secreting extracellular polysaccharides and the 
325 quantity and composition of these extracellular polysaccharides may affect the attachment

326 properties of the bacteria (Sanin et al. 2003). This would suggest that bacterial pathogen

327 attachment to algae and suspended solids could be an important mechanism for bacteria removal

328 (Ansa et al. 2011).

330 However, a study by Boutilier et al. (2009) examining sedimentation of E. coli reported that 331 settling did not appear to significantly contribute to E. coli removal in 5-day sedimentation

332 experiments during which $E$. coli remained in suspension and $10 \%$ and $50 \%$ of $E$. coli in 333 domestic dairy wastewater and septic tank effluent, respectively, associated with particulate 334 matter. The role of sedimentation in pathogen removal has been reported to range from 0 to $100 \%$

335 (Maynard et al. 1999). Some studies demonstrated that the performance of WSPs in removing 336 protozoan cysts and helminth eggs could primarily be attributed to the process of sedimentation 337 favoured by the adsorption of the pathogens onto settable solids, as well as relatively long 338 retention times (Amahmid et al. 2002; Mara 2003). Conversely, Reinoso et al. (2011) noticed a 339 negligible influence on oocyst removal through sedimentation in facultative and maturation 340 ponds with $0 \%$ and $5.56 \%$ of Cryptosporidium oocysts removed through sedimentation in the 341 facultative and maturation ponds, respectively.

343 Reinoso et al. (2011) suggested that anaerobic ponds were the most effective in parasite removal

344 followed by facultative ponds and then maturation ponds. These findings were consistent with 345 those previously reported, which indicated that the majority of (oo)cysts, eggs and suspended 346 solid material are generally removed in primary ponds (Jimenez et al. 2001; Reinonso et al. 347 2011). However, contrary to previous studies crediting sedimentation as a main mechanism for 
348 parasites removal in stabilization ponds, results presented by Reinonso et al. (2011) indicated 349 that the physicochemical environment (light, $\mathrm{pH}, \mathrm{DO}$, ammonia concentration, etc.) of the pond 350 could also be a significant factor in the removal of parasites from these systems.

\section{Retention time \& Pond depth}

353 HRT in WSPs is defined as the average hydraulic period that wastewater remains in pond 354 systems prior to discharge into a receiving environment. It is an important factor that impacts the 355 die-off and the removal of pathogens. Sedimentation in ponds is dependent on HRT, since longer 356 HRTs allow more time for the settling of suspended particles to which pathogens may be 357 attached (Metcalf and Eddy 2003). Also, longer retention times provide a longer period of time 358 for pathogen inactivation or removal via factors that contribute to disinfection such as sunlight, $359 \mathrm{pH}, \mathrm{DO}$ and temperature.

361 In a constructed wetland study, the E. coli removal efficiency was $91 \%$ for wetlands with 11.6 362 day HRT, while for wetlands with a HRT of 0.9 day, the E. coli removal efficiency was $66 \%$ 363 (Diaz et al. 2010). Moreover, of all the parameters ( $\mathrm{pH}$, total nitrogen (TN), nitrate, total 364 phosphorus (TP), dissolved organic carbon (DOC), total suspended solids (TSS), temperature, 365 DO, Chlorophyll-a, E. coli and Enterococci) compared in the study, HRT appeared to be the 366 factor having the greatest effect on the efficiency of E. coli and Enterococci removal (Diaz et al. 367 2010). HRT and the loading rate were two of the most important factors for removing fecal 368 coliforms and total coliforms in a pilot-scale combined constructed wetland system (Tuncsiper et 369 al. 2012). In domestic wastewater, Feacham et al. (1983) proposed a time period of 30-60 days 370 for pathogenic bacteria removal. Jiménez et al. (2001) indicated that a minimum retention time 
371 of 5-20 days, depending on the initial concentration, was required to efficiently remove helminth

372 eggs, while 38 days would be necessary to remove protozoan (oo)cysts. Grimason et al. (1996a;

373 b) showed that an HRT of 25.3 days would be sufficient for the removal of Ascaris eggs and

374 Giardia cysts in Eldoret, Kenya. However, 40 days would be required to accomplish the same

375 performance in Meze, France. It should be noted, that these retention times are longer than the 8-

37610 days recommended in the WHO guidelines, to achieve a standard of 1 helminth ovum per liter

377 (WHO 1989; Awuah 2006). The different concentrations and sizes of protozoa and helminthes,

378 which yielded different settling velocities, may explain these variations in recommended

379 retention times (Reinoso et al. 2007).

380

381 A baffle applied to a WSP system can extend HRT. Only the baffled maturation pond showed a

382 significant removal of fecal bacteria, viruses and protozoa when four maturation ponds (one with

383 baffle and three without baffle) were compared (Sheludchenko et al. 2016). After introducing

384 baffles to the first maturation pond, the HRT was increased by 14 hours, and the removal

385 efficiency of both E. coli and Enterococci was raised by 0.2 to $0.7 \log$ unit at Korba wastewater

386 treatment plant which consisted of a conventional activated sludge system followed by three

387 maturation ponds (Ouali et al. 2012).

389 Depth may increase retention period, but it may also decrease sunlight penetration in algal ponds

390 which would present confounding results with respect to disinfection mechanisms. Mayo (1989)

391 found that, while fecal bacteria reduction in wastewater was observed to increase with solar

392 intensity and hydraulic retention time, it was also noted to decrease with depth. Agunwamba

393 (1991) and Pearson et al. (1995) also reported reductions in pond efficiencies with respect to 
394 bacteria die-off rates in deeper ponds. Many pond system designers have indicated that 395 increasing pond depth, and thus retention time, would lead to better overall pond performance, 396 however, this may not be applicable for disinfection (Pearson et al. 1995; Mara et al. 2001). 397 Buchauer (2007) found that shallower maturation ponds were generally more efficient for FC 398 removal.

\section{Predation \& Presence of other microorganisms}

401 Another way to remove pathogens from wastewater is through the presence of other 402 microorganisms that consume or compete with the pathogenic organisms. Protozoa prey on 403 organisms such as bacteria, yeasts, algae and other protozoa (Storer et al. 1979). Predation is an 404 important factor in the removal of bacteria and protozoan (oo)cysts from wastewaters in CWs 405 (Jasper et al. 2013; Wu et al. 2016). MacCambridge and MacMeekin (1979; 1980) demonstrated 406 the importance of protozoan predation on E. coli removal. Kim and Unno (1996) showed that the 407 predation of viruses by protozoa was more effective than that of bacteria by protozoa. Some 408 protozoa have been identified to feed on FC, as well as diptherial, cholera, typhal and 409 streptococcal bacteria species (MacCambridge and MacMeekin 1979; Wu et al. 2016). FC 410 number in a duckweed pond system correlated well with total ostracod numbers in the pond, 411 suggesting that macro-invertebrate feedings could contribute to FC removal in duckweed ponds 412 (Ansa et al. 2012). In constructed wetlands, predation of Cryptosporidium oocysts by ciliates 413 such as Euplotes patella and Paramecium caudatum has been reported as a mechanism for 414 pathogen removal (Stott et al. 2003; Awuah 2006). 
416 The presence of other bacteria might affect pathogen removal through the competition for

417 nutrients. According to Atlas and Bartha (1981), intestinal bacteria and other pathogen

418 populations were reduced and eventually eliminated through competition with aquatic

419 autochthonous bacteria populations. It has been suggested that understanding nutrient availability

420 and competition for these nutrients in heterotrophic bacteria communities are important factors in

421 determining fecal bacteria die-off rates (Klock 1971; Wu and Klein 1976; Legendre et al. 1984).

422 Competition between heterotrophic bacteria for nutrients and its effects on pathogen removal in

423 pond systems have not been thoroughly investigated.

424

\section{$425 \quad$ Nutrients and organic loading}

426 The nutrient level and organic loading of a WSP will affect the survival and regrowth of 427 pathogenic microorganisms. A number of studies have reported on the importance of nutrient 428 availability to the survival and growth of microorganisms (Almasi and Pescod 1996; Kaneko 429 1997; Gagliardi and Karns 2000; Diaz et al. 2010). Boutilier et al. (2009) reported that E. coli 430 survived for a longer period of time in dairy wastewaters, which normally have higher nutrient 431 concentrations than municipal wastewaters. High nutrient concentrations have been shown to 432 generally decrease the rate of pathogen removal in wastewater systems (Gagliardi and Karns 433 2000; Diaz et al. 2010). Diaz et al. (2010) observed a positive correlation between indicator 434 organisms and DOC, TP, TN and nitrate concentration in a constructed surface flow wetland. In 435 their study, E. coli concentration was positively correlated with TP $(\mathrm{r}=0.521 ; \mathrm{p}<0.01)$, while 436 Enterococci concentrations were positively correlated with $\mathrm{TN}$ and nitrate $(\mathrm{r}=0.357$ and $\mathrm{r}=0.378$, 437 respectively; $\mathrm{p}<0.01)$. 


\section{Conclusions}

440 It has been commonly noted in literature that traditional indicator organisms (E. coli, TC and FC)

441 do not accurately represent the potential presence of all pathogens, which may respond

442 differently to various environmental or exposure factors. These may be subject to different

443 removal mechanisms than indicator organisms. It is also unclear to what extent fecal indicator

444 organisms are representative of the pathogenic organisms of concern. More research is required

445 to gain a better understanding of the distribution of pathogenic organisms in WSPs and to select

446 appropriate additional or alternative indicator organisms. A number of different bacterial, viral,

447 protozoan and helminthic pathogens have been proposed as additional or alternative indicators

448 for monitoring wastewater effluent quality. However, the correlation between these indicators

449 has rarely been studied for the purpose of minimizing the number of pathogen indicators. This

450 will become increasingly relevant to municipalities with the growing number of persistent

$451 \mathrm{drug} /$ disinfection resistant microorganisms are introduced into wastewater systems and

452 subsequently discharged into receiving environments.

454 Recent work has considered pathogen removal as a complex mechanism involving interactions 455 between the different physical, chemical and biological processes present in WSP systems. Many 456 factors and mechanisms, including sunlight, $\mathrm{pH}, \mathrm{DO}$, temperature, sedimentation, retention time, 457 predation and nutrients, contribute to pathogen removal, however, the literature presents 458 conflicting information with respect to the governing mechanism. These results reinforce the 459 idea that pathogen removal may not rely simply on one or two factors, but instead, on multiple 460 factors, with many of these removal mechanisms interdependent or interrelated. Some research 461 has demonstrated correlations between these factors, but further studies are necessary to gain a 
462 better understanding of the removal factors as well as their correlations, particularly in colder

463 climates where a number of these natural disinfection mechanisms, direct and indirect, will be

464 governed by variations climate, particularly sunlight and temperature.

465

466 Algae play a unique role in pond systems. They are able to uptake nutrients, such as nitrogen and

467 phosphorus in both inorganic and organic forms. In addition to their role in nutrient removal, 468 algae have been recognized as an indirect disinfection factor, especially in natural wastewater 469 treatment processes. For example, algae are able to raise $\mathrm{pH}$ and $\mathrm{DO}$ concentrations through 470 photosynthesis. $\mathrm{pH}$ levels above 9 have been demonstrated to be bactericidal in WSPs. DO can 471 also inactivate pathogenic organisms at concentrations higher than $0.5 \mathrm{mg} / \mathrm{L}$. The photo472 oxidation that occurs in pond systems is enhanced by the presence of high DO concentrations, 473 which is a product of algal photosynthesis. Therefore, it is essential to study the role of algae in

474 the disinfection process in WSPs in order to better understand and correlate important pathogen 475 removal factors such as sunlight, $\mathrm{pH}$ and DO. This would provide invaluable insights to 476 operators of WSP systems. The design and operation of the eco-engineered systems could be

477 tailored to promote natural disinfection conditions as a function of anticipated climate and 478 seasonal variations, which would enable small, remote and rural communities - where these 479 systems are largely operated - to better predict their effluent water quality and assist them in 480 meeting increasingly stringent effluent discharge requirements.

482 Acknowledgements

483 The authors are grateful for the funding provided by the Canadian Water Network (CWN) and 484 the Natural Sciences and Engineering Research Council (NSERC) under STEWARD CREATE 
485

486

487

488

489

490

491

492

493

494

495

496

497

498

499

500

501

502

503

504

505

506

507

508

and CRD program grants for this project, as well as the Canada Research Chairs program. A special thank you to J. Pernari for her assistance with illustrations.

\section{References}

Agunwamba, J. C. 1991. Dispersion Number Determination in Waste Stabilization Ponds. Water Air Soil Pollut. 59(3-4): 241-247. doi:10.1007/BF00211833.

Al-Hashimi, M., Hussain, H.T. 2013. Stabilization Pond for Wastewater Treatment, Euro. Sci. J. 9(14): 278-294. Available from file:///Users/Lei/Downloads/1084-3234-1-PB.pdf [accessed on 27 December 2017].

Almasi, A., and Pescod, M.B. 1996. Pathogen removal mechanisms in anoxic wastewater stabilization ponds. Water Sci. Technol. 33(7): 133-140. doi:10.1016/0273-1223(96)00348-4.

Amahmid, O., Asmama, S., and Bouhoum, K. 2002. Urban wastewater treatment in stabilization ponds: occurrence and removal of pathogens. Urban Water. 4(3): 255-262. doi:10.1016/S1462-0758(01)00071-1.

Ansa, E.D.O., Lubberding, H.J., Ampofo, J.A., and Gijzen, H.J. 2011. The role of algae in the removal of Escherichia coli in a tropical eutrophic lake. Ecol. Eng. 37(2011): 317-324. doi: 10.1016/j.ecoleng.2010.11.023.

Ansa, E.D.O., Lubberding, H.J., Ampofo, J.A., Amegbe, G.B., and Gijzen, H.J. 2012. Attachment of fecal coliform and macro-invertebrate activity in the removal of fecal coliform in domestic wastewater treatment pond systems. Ecol. Eng. 42(2012): 35-41.

Atlas, R.M., and Bartha, R. 1981. Microbial ecology; Fundamentals and applications. Addison Wesley Publishers Co. London. pp. 560.

Awuah, E. 2006. Pathogen removal mechanisms in waste stabilisation ponds. Ph.D. thesis, Wageningen University/UNESCO-IHE Institute for Water Education, The Netherlands. 
Awuah, E., Anohene, F., and Asante, K. 2001. Environmental conditions and pathogen removal

510 in macrophyte- and algal-based domestic wastewater treatment systems. Water Sci. Technol.

$511 \quad 44(6): 11-18$.

512 Awuah, E., Lubberding, H.J., and Asante, K. 2002. The effect of $\mathrm{pH}$ on enterococci removal in

513 Pistia-, duckweed- and algae-based stabilization ponds for domestic wastewater treatment.

$514 \quad$ Water Sci. Technol. 45(1): 67-74.

515 Bales, R.C., Li, S.M., Maguire, K.M., Yahya, M.T. and Gerba, C.P. 1993. MS-2 and poliovirus

516 transport in porous medium: Hydrophobic effects and chemical perturbations. Water Resour.

517 Res. 29(4): 957-963.

518 Bales, R.C., Li, S., Yeh, T.C.J., and Lenczewski, M.E.C.P. 1997. Bacteriophage and microsphere

519 transport in saturated porous medium: Force-gradient experiment at Borden, Ontario. Water $520 \quad$ Resour. Res. 33: 639-648.

521 Barzily, A., and Kott, Y. 1991. Survival of pathogenic bacteria in an adverse environment. Water 522 Sci. Technol. 24(2): 395-400.

523 Baxter, C.S., Hofmann, R., Templeton, M.R., Brown, M., and Andrews, R.C. 2007. Inactivation 524 of adenovirus types 2, 5, and 41 in drinking water by UV light, free chlorine, and 525 monochloramine. J. Environ. Eng. 133(1): 95-103.

526 Berney, M., Weilenmann, H.U., and Egli, T. 2006a. Flow-cytometric study of vital cellular 527 functions in Escherichia coli during solar disinfection (SODIS). Microbiol. Sgm. 152: 1719$528 \quad 1729$.

529 Berney, M., Weilenmann, H.U., and Egli, T., 2006b. Gene expression of Escherichia coli in 530 continuous culture during adaptation to artificial sunlight. Environ. Microbiol. 8: 1635-1647.

531 Bolton, N.F., Cromar, N.J., Hallsworth, P., and Fallowfield, H.J. 2010. A review of the factors 
affecting sunlight inactivation of microorganisms in waste stabilization ponds: preliminary results for enterococci. Water Sci. Technol. 61: 885-890. doi: 10.2166/wst.2010.958.

Bolton, N.F., Cromar, N.J., Buchanan, N.A., and Fallowfield, H.J. 2011. Mechanisms of sunlight inactivation of common microbial indicators in waste stabilization ponds. In Proceedings of the 9th IWA Specialist Group Conference on Waste Stabilization Ponds: Adelaide, Australia, 1-3 August 2011.

Bosshard, F., Bucheli, M., Meur, Y., and Egli, T. 2010a. The respiratory chain is the cell's Achilles' heel during UVA inactivation in Escherichia coli. Microbiol. 156: 2006-2015. doi:10.1099/mic.0.038471-0.

Bosshard, F., Riedel, K., Schneider, T., Geiser, C., Bucheli, M., and Egli, T. 2010b. Protein oxidation and aggregation in UVA irradiated Escherichia coli cells as signs of accelerated cellular senescence. Environ. Microbiol. 12(11): 2931-2945. doi:10.1111/j.1462-

$$
\text { 2920.2010.02268.x. }
$$

Boutilier, L., Jamieson, R., Gordon, R., Lake, C., and Hart, W. 2009. Adsorption, sedimentation, and inactivation of E. coli within wastewater treatment wetlands. Water Res. 43(17): 4370-

550 Champagne, P., Liu, L., and Howell, M. 2017. Aerobic treatment in cold-climate countries. In 551 Current development in biotechnology and bioengineering. Elsevier, Amsterdam, 552 Netherlands. pp. 161-189.

553 Cornejo, P.K., Zhang, Q., and Mihelcic, J.R. 2013. Quantifying benefits of resource recovery 554 from sanitation provision in a developing world setting. J. Environ. Manag. 131: 7-15. 
doi:10.1016/j.jenvman.2013.09.043.

556 Cromeans, T.L., Kahler, A.M., and Hill, V.R. 2010. Inactivation of adenoviruses, enteroviruses, 557 and murine norovirus in water by free chlorine and monochloramine. Appl. Environ. 558 Microbiol. 76(4): 1028-1033. doi:10.1128/AEM.01342-09.

559 Curtis, T.P., Mara, D.D., and Silva, S.A. 1992a. Influence of pH, oxygen, and humic substances 560 on ability of sunlight to damage fecal coliforms in waste stabilization pond water. Appl. $561 \quad$ Environ. Microbiol. 58(4): 1335-1343.

562 Curtis, T.P., Mara, D.D., and Silva, S.A. 1992b. The effect of sunlight on faecal coliforms in 563 ponds: implications for research and design. Water Sci. Technol. 26(7-8): 1724-1738.

564 Curtis, T.P., Mara, D.D., Dixo, N.G.H., and Silva, S.A. 1994. Light penetration in waste 565 stabilization ponds. Wat. Res. 28: 1031-1038.

566 Davies-Colley, R.J., Bell, R.G., and Donnison, A.M. 1994. Sunlight inactivation of enterococci 567 and fecal-coliforms in sewage effluent diluted in seawater. Appl. Environ. Microbiol. 60: $568 \quad 2049-2058$.

569 Davies-Colley, R.J., Donnison, A.M., and Speed, D.J. 1997. Sunlight wavelengths inactivating 570 faecal indicator microorganisms in waste stabilization ponds. Water Sci. Technol. 35(11-12): $571219-225$.

572 Davies-Colley, R.J., Donnison, A.M., Speed, D.J., Ross, C.M., and Nagels, J.W. 1999. 573 Inactivation of faecal indicator microorganisms in waste stabilization ponds: interaction of 574 environmental factors with sunlight. Water Res. 33(5): 1220-1230.

575 Davies-Colley, R.J., Donnison, A.M., and Speed, D.J. 2000. Towards a mechanistic 576 understanding of pond disinfection. Water Sci. Technol. 42: 149-158.

577 Diaz, F.J., O'Geen, A.T., and Dahlgren, R.A. 2010. Efficacy of constructed wetlands for removal 
578 of bacterial contamination from agricultural return flows. Agric. Water Manag. 97(11): 1813579 1821. doi:10.1016/j.agwat.2010.06.015.

580 Drechsel, P., Scott, C.A., Raschid-Sally, L., Redwood, M., and Bahri, A. 2009. Wastewater 581 irrigation and health-assessing and mitigating risk in low-income countries. International 582 Water Management Institute and International Development Research Centre, London, UK.

583 Fallowfield, H.J., Cromar, N.J., and Evison, L.M. 1996. Coliform die-off rate constants in a high 584 rate algal pond and the effect of operational and environmental variables. Water Sci. Technol. 34(11): 141-147. doi:10.1016/S0273-1223(96)00831-1.

586 Feachem, R.G., Bradley, D.J., Garelick, H., and Mara, D.D. 1983. Sanitation and Disease: Health 587 Aspects of Excreta and wastewater management. Published for the World Bank by John $588 \quad$ Wiley and Sons, U.K.

589 Ferro, S., Coppellotti, O., Roncucci, G., Ben Amor, T., and Jori, G. 2006. Photosensitized $590 \quad$ inactivation of Acanthamoeba palestinensis in the cystic stage. J. Appl. Microbiol. 101: 206212. doi:10.1111/j.1365-2672.2006.02893.x.

592 Fisher, M.B., Iriarte, M., and Nelson, K.L. 2012. Solar water disinfection (SODIS) of 593 Escherichia coli, Enterococcus spp., and MS2 coliphage: effects of additives and alternative 594 container materials. Water Res. 46(6): 1745-1754. doi:10.1016/j.watres.2011.12.048.

595 Gagliardi, J.V., and J.S. Karns. 2000. Leaching of Escherichia coli O157:H7 in diverse soils 596 under various agricultural management practices. Appl. Environ. Microbiol. 66:877-883. 597 doi:10.1128/AEM.66.3.877-883.2000.

598 George, I., Crop, P., and Servais, P. 2002. Faecal coliform removal in wastewater treatment 599 plants studied by plate counts and enzymatic methods. Water Res. 36(10): 26072617. 
601 Grimason, A.M., Smith, H.V., Young, G., and Thitai, W.N. 1996a. Occurrence and removal of 602 Ascaris sp. ova by waste stabilisation ponds in Kenya. Water Sci. Technol. 33(7): 75-82. 603 doi:10.1016/0273-1223(96)00341-1.

604 Grimason, A.M., Wiandt, S., Baleux, B., Thitai, W.N., Bontoux, J., and Smith, H.V. 1996 b. 605 Occurrence and removal of Giardia sp cysts by Kenyan and French waste stabilisation pond 606 systems. Water Sci. Technol. 33(7): 83-89. doi:10.1016/0273-1223(96)00342-3.

607 Guan, H., Schulze-Makuch, D., Schaffer, S., and Pillai, S.D. 2003. The effect of critical pH on 608 virus fate and transport in saturated porous medium. Ground Water 41(5): 701-708.

609 Heaselgrave, W., Patel, N., Kilvington, S., Kehoe, S.C., and McGuigan, K.G. 2006. Solar 610 disinfection of poliovirus and Acanthamoeba polyphaga cysts in water - a laboratory study 611 using simulated sunlight. Lett. Appl. Microbiol. 43(2):125-30. doi:10.1111/j.1472$612 \quad 765 X .2006 .01940 . x$

613 Hillebrandt, S., and Müller, I.1991. Repair of damage caused by UV- and X-irradiation in the 614 amoeboflagellate Naegleria gruberi. Radiat. Environ. Biophys. 30(2): 123-30.

615 Hijnen, W.A.M., Beerendonk, E.F., and Medema, G.J. 2006. Inactivation credit of UV radiation 616 for viruses, bacteria and protozoan (oo)cysts in water; a review. Wat. Res. 40(1): 3-22. 617 doi:10.1016/j.watres.2005.10.030.

618 Hotze, E.M., Badireddy, A.R., Chellam, S., and Wiesner, M.R. 2009. Mechanisms of 619 bacteriophage inactivation via singlet oxygen generation in UV illuminated fullerol 620 suspensions. Environ. Sci. Technol. 43(17): 6639-6645.

621 Hwang, T.S., Hyon, J.Y., Song, J.K., Reviglio, V.E., Spahr, H.T., and O’Brien, T.P. 2004. 622 Disinfection capacity of PuriLens contact lens cleaning unit against Acanthamoeba. Eye 623 Contact Lens 30:42-43. 
624 Jasper, J.T., Nguyen, M.T., Jones, Z.L., Ismail, N.S., Sedlak, D.L., Sharp, J.O., Luthy, R.G.,

625 Horne, A.J., and Nelson, K.L. 2013. Unit process wetlands for removal of trace organic 626 contaminants and pathogens from municipal wastewater effluents. Environ. Eng. Sci. 30(8): 627 421-436. doi:10.1089/ees.2012.0239.

628 Jiménez, B. 2007a. Helminth ova removal from wastewater for agriculture and aquaculture 629 reuse. Water Sci. Technol. 55(1-2): 485-493. doi: 10.2166/wst.2007.046.

630 Jiménez, B. 2007b. Helminth ova control in sludge: a review. Water Sci. Technol. 56(9):147$631 \quad 155$.

632 Jiménez, B., Maya-Rendón, C., and Salgado-Velázquez, G. 2001. The elimination of helminth 633 ova, faecal coliforms, Salmonella and protozoan cysts by various physicochemical processes 634 in wastewater and sludge. Water Sci. Technol. 43(12): 179-182

635 Jiménez, B. 2009. Helminth ova control in wastewater and sludge for agricultural reuse. In 636 book: Water Reuse New Paradigm towards Integrated Water Resources Management in 637 Encyclopedia of Biological, Physiological and Health Sciences, Edition: 1a, Publisher: 638 EOLSS Publishers Co. Ltd UNESCO, Editors: Grabow W., pp. 429-449.

639 Jokerst, A., Sharvelle, S.E., Hollowed, M.E., and Roesner, L.A. 2011. Seasonal performance of 640 an outdoor constructed wetland for graywater treatment in a temperate climate. Water 641 Environ. Res. 83(12): 2187-2198. doi:10.2175/106143011X12989211841412.

642 Kadir, K., and Nelson, K.L. 2014. Sunlight mediated inactivation mechanisms of Enterococcus 643 faecalis and Escherichia coli in clear water versus waste stabilization pond water. Water Res. $644 \quad$ 50: $307-317$. doi: $10.1016 /$ j.watres.2013.10.046.

645 Kaneko, J., Kimura, T., Kawakami, Y., Tomita, T., and Kamio, Y. 1997. Panton-valentine 646 leukocidin genes in a phage-like particle isolated from mitomycin C-treated Staphylococcus 
aureus V8 (ATCC 49775). Biosci. Biotechnol. Biochem. 61(11): 1960-1962. doi:10.1271/bbb.61.1960.

649 Kim, T.D., and Unno, H. 1996. The roles of microbes in the removal and inactivation of viruses

650 in a biological wastewater treatment system. Water Sci. Technol. 33(10):243-250. 651 doi:10.1016/0273-1223(96)00426-X.

652 Klock, J. W. 1971. Survival of Coliform Bacteria in Wastewater Treatment Lagoons. J. Water 653 Pollut. Control. Fed. 43(10): 2071-2083.

654 Kohn, T., and Nelson, K.L. 2007. Sunlight-mediated inactivation of MS2 coliphage via 655 exogenous singlet oxygen produced by sensitizers in natural waters. Environ. Sci. Technol. 41(1): 192-197. doi:10.1021/es061716i.

657 Koivunen, J., Siitonen, A., and Tanski, H.H. 2003. Elimination of enteric bacteria in biological658 chemical wastewater treatment and tertiary filtration units. Water Res., 37: 690-698. doi: $659 \quad 10.1016 / \mathrm{S} 0043-1354(02) 00305-6$.

660 Li, J.W., Xin, Z.T., Wang, X.W., Zheng, J.L., and Chao, F.H. 2004. Mechanisms of inactivation 661 of hepatitis A virus in water by chlorine dioxide. Water Res. 38(6): 1514-1519. 662 doi:10.1016/j.watres.2003.12.021.

663 Liu, L., Hall, G., and Champagne, P. 2015. Effects of environmental factors on the disinfection 664 performance of a wastewater stabilization pond operated in a temperate climate. Water 8(5):111. doi:10.3390/w8010005.

Liu, L. 2018. The role of algae in disinfection processes in wastewater stabilization ponds. Ph.D.

667 dissertation. Queen’s University, Kingston, ON.

668 Loret, J. F., Jousset, M., Robert, S., Saucedo, G., Ribas, F., Thomas, V., and Greub, G. 2008. 669 Amoebae-resisting bacteria in drinking water: risk assessment and management. Water Sci. 


$$
\text { Technol. 58(3): 571-577. doi:10.2166/wst.2008.423. }
$$

671 Love, D.C., Silverman, A., and Nelson, K.L. 2010. Human virus and bacteriophage inactivation 672 in clear water by simulated sunlight compared to bacteriophage inactivation at a Southern 673 California Beach. Environ. Sci. Technol. 44(18): 6965-6970. doi:10.1021/es1001924.

674 MacDougall, A. 2016. The effects of climate and humic substances on disinfection performance 675 in Arctic wastewater stabilization pond. Master's Thesis, Department of Civil Engineering, 676 Queen's University, Kingston, ON, Canada.

677 McCambridge, J., and McMeekin, T.A. 1979. Protozoan predation of Escherichia coli in 678 estuarine waters. Water Res. 13: 659-664. doi:10.1016/0043-1354(79)90016-2.

679 McCambridge, J., and McMeekin, T.A. 1980. Relative effects of bacterial and protozoan 680 predators on survival of Escherichia coli in estuarine water samples. Appl. Environ. 681 Microbiol. 40: 907-911.

682 Mahler, B.J., Personne, J.C., Lods, G.F., and Drogue, C. 2000. Transport of free and particulate683 associated bacteria in karst. J. Hydrol. 238(3-4): 179-193. doi:10.1016/s0022-1694(00)003246843.

685 Mara, D.D. 2003. Domestic Wastewater Treatment in Developing Countries. In Domestic 686 Wastewater Treatment in Developing Countries Earthscan/James \& James, London, UK.

687 Mara, D.D., and Pearson, H.W. 1986. Artificial freshwater environments: waste stabilization 688 ponds. In Schoernborn W Biotechnology, Weinheim, Germany: VCH Verlagsgesellschaft, pp. $689 \quad 177-206$.

690 Mara, D.D, Pearson, H., Oragui, J., Arridge, H., and Silva, S.A. 2001. Development of a New 691 Approach to Waste Stabilization Pond Design. Research Monograph No. 5, pp. 1-56. School 692 of Civil Engineering, University of Leeds, Leeds, England. 
693 Marais, G.V. 1974. Fecal bacterial kinetics in stabilization ponds. J. Sanit. Eng. Div. Am. Soc.

694 Civ. Eng. 100:119-139.

695 Mayo, A.W.1989. Effect of Pond Depth on Bacterial Mortality Rate. J. Environ. Eng. 115(5):

$696964-976$.

697 Maynard, H.E., Ouki, S.K., and Williams, S.C. 1999. Tertiary lagoons: a review of removal 698 mechanisms and performance. Water Res. 33(1): 1-13. doi: 10.1016/s0043-1354(98)00198-5.

699 Metcalf and Eddy Inc. 2003. Wastewater Engineering: Treatment and reuse. In Wastewater 700 Engineering: Treatment and reuse. 4th ed. McGraw Hill Inc. New York, USA.

701 Mezrioui N., Oufdou K., and Baleux, B. 1995a. Dynamics of non-01 Vibrio cholerae and faecal 702 coliforms in experimental stabilization ponds in the arid region of Marrakesh, Morocco, and 703 the effect of $\mathrm{pH}$, temperature, and sunlight on their experimental survival. Can. J. Microbiol. $704 \quad$ 41(6): 489-498.

705 Mezrioui, N., Baleaux, B., and Troussellier, M. 1995b. A microcosm study of the survival of 706 Escherichia coli and Salmonella typhimurium in brackish water. Wat. Res. 29: 459-465.

707 Mo, W., and Zhang, Q. 2012. Can municipal wastewater treatment systems be carbon neutral? J. 708 Environ. Manag. 112: 360-367. doi:10.1016/j.jenvman.2012.08.014.

709 Mosteo, R., Ormad, M.P., and Goni, P. 2013. Identification of pathogen bacteria and protozoa in 710 treated urban wastewaters discharged in the Ebro River (Spain): water reuse possibilities. 711 Water Sci. Technol. 68(3): 575-583. doi: 10.2166/wst.2013.201.

712 Moumouni, D.A., Andrianisa, H.A., Konate, Y., Ndiaye, A., and Maiga, A. 2016. Inactivation of 713 Escherichia coli in a baffled pond with attached growth: treating anaerobic effluent under the 714 Sahelian climate. Environ. Technol. 37(9): 1054-1064. doi: 10.1080/09593330.2015.1098732.

715 Nelson, K.L., Kadir, K., Fisher, M.B., and Love, D. 2009. New insights into sunlight disinfection 
716 mechanisms in waste stabilisation ponds. 8th IWA Specialist Group Conference on Waste

717 Stabilisation Ponds Belo Horizonte, Brazil, 26-30 April 2009.

718 Nuanualsuwan, S., Miriam, T., Himathongham, S., and Cliver, D.O. 2002. Ultraviolet 719 inactivation of feline calicivirus, human enteric viruses and coliphages. Photochem. 720 Photobiol. 76: 406-410. doi:10.1562/0031-8655(2002)076<0406:UIOFCH>2.0.CO;2.

721 Oilgae 2009. Oilgae guide to algae-based wastewater treatment. In Oilgae guide to algae-based 722 wastewater treatment. Tamilnadu, India. pp. 5-21.

723 Ouali, A., Jupsin, H., Ghrabi, A., and Vasel, J.L. 2014. Removal kinetic of Escherichia coli and 724 enterococci in a laboratory pilot scale wastewater maturation pond. Water Sci. Technol. 69(4): $725755-759$. doi: $10.2166 /$ wst.2013.774.

726 Ouali, A., Jupsin, H., Vasel, J.L., Marouani, L., and Ghrabi, A. 2012. Removal improvement of 727 bacteria (Escherichia coli and Enterococci) in maturation ponds using baffles. Water Sci. 728 Technol. 65(4): 589-595. doi: 10.2166/wst.2012.896.

729 Pearson, H.W., Mara, D.D., Mills, S.W., and Smallman, D.J. 1987a. Factors determining algal 730 populations in waste stabilization ponds and influence on algae pond performance. Water Sci. 731 Tech. 19(12): 131-140.

732 Pearson, H.W., Mara, D.D., Mills, S.W., and Smallman, D.J. 1987b. Physiochemical parameters 733 influencing faecal bacteria survival in waste stabilization ponds. Water Sci. Tech., 19(12): $734 \quad 145-152$.

735 Pearson, H.W., Mara, D.D., and Arridge, H.A. 1995. The Influence of Pond Geometry and 736 Configuration on Facultative and Maturation Waste Stabilization Pond Performance and 737 Efficiency. Water Sci. Technol., 31(12): 129-139. doi:10.1016/0273-1223(95)00500-M.

738 Polprasert, C., Dissanayake, M.G., and Thanh, N.C. 1983. Bacterial die-off kinetics in waste 
stabilization ponds. J. Water Pollut. Control Fed. 55: 285-296.

740 Reinoso, R., and Bécares, E. 2008. Environmental inactivation of Cryptosporidium parvum 741 oocysts in waste stabilization ponds. Microb. Ecol. 56(4): 585-592. doi:10.1007/s00248-008$742 \quad 9378-7$.

743 Reinoso, R., Blanco, S., Torres-Villamizar, L., and Bécares, E. 2011. Mechanisms for parasites 744 removal in a waste stabilization pond. Microb. Ecol. 61(3): 648-692. doi:10.1007/s00248745 010-9791-6.

Reinoso, R., Bécares, E., and Smith, H.V. 2007. Effect of various environmental factors on the 747 viability Cryptosporidium parvum oocysts. J. Appl. Microbiol. 104: 980-986. 748 doi:10.1111/j.1365-2672.2007.03620.x.

749 Rose, J.B., Farrah, S.R., Harwood, V.J., Levine, A.D., Lukasik, J., Menendez, P., and Scott, 750 T.M. 2004. Reduction of pathogens, indicator bacteria, and alternative indicators by 751 wastewater treatment and reclamation processes. Water Environment Research Foundation, 752 Alexandria, VA, US.

753 Sanin, S.L., Sanin, F.D., and Bryers, J.D. 2003. Effect of starvation on the adhesive properties of 754 xenobiotic degrading bacteria. Process Biochem. 38: 909-914. doi:10.1016/S0032$7559592(02) 00173-5$.

756 Sano, D., Pinto, R.M., Omura, T., and Bosch, A. 2009. Detection of oxidative damages on viral 757 capsid protein for evaluating structural integrity and infectivity of human norovirus. Environ. 758 Sci. Technol. 44(2): 808-812. doi:10.1021/es9018964.

759 Santos, A.L., Oliveira, V., Baptista, I., Henriques, I., Gomes, N.C.M., Almeida, A., Correia, A., 760 and Cunha, A. 2012. Wavelength dependence of biological damage induced by UV radiation 761 on bacteria. Arch. Microbiol. 195: 63-74. doi:10.1007/s00203-012-0847-5. 
762 Sarikaya, H. Z., and Saatci, A. M. 1987. Bacteria die-off in waste stabilization ponds. J. Environ. 763 Eng. 113(2): 366-382.

764 Sassoubre, L.M., Nelson, K.L., and Boehm, A.B. 2012. Mechanisms for photoinactivation of 765 Enterococcus faecalis in Seawater. Appl. Environ. Microbiol. 78: 7776-7785. 766 doi:10.1128/AEM.02375-12.

767 Sengupta, M.E., Thamsborg, S.M., Andersen, T.J., Olsen, A., and Dalsgaard, A. 2011 768 Sedimentation of helminth eggs in water. Water Res. 45(15): 4651-4660. 769 doi:10.1016/j.watres.2011.06.017.

770 Sharafi, K., Moradi, M., Karami, A., and Khosravi, T. 2015 Comparison of the efficiency of 771 extended aeration activated sludge system and stabilization ponds in real scale in the removal 772 of protozoan cysts and parasite ova from domestic wastewater using Bailenger method: a case 773 study, Kermanshah, Iran. Desalination water treatment, 56(5): 1135-1141. 774 doi:10.1080/19443994.2014.923333

775 Sheludchenko, M., Padovan, A., Katouli, M., and Stratton, H. 2016. Removal of Fecal 776 Indicators, Pathogenic Bacteria, Adenovirus, Cryptosporidium and Giardia (oo)cysts in Waste 777 Stabilization Ponds in Northern and Eastern Australia. Int. J. Environ. Res. Pub. Health 13(1): 778 96. doi:10.3390/ijerph13010096.

779 Siddiqui, R., and Khan, N.A. 2008. Balamuthia amoebic encephalitis: an emerging disease with 780 fatal consequences. Microbiol. Pathog. 44(2): 89-97. doi:10.1016/j.micpath.2007.06.008.

781 Storer, T.I., Usinger, R.L., Stebbins, R.C., and Nybakken, J.W. 1979. Protozoans. In General 782 Zoology, 6th Edition. McGraw-Hill, New York, pp. 329-359.

783 Stott R., May E., and Mara D.D. 2003. Parasite removal by natural wastewater treatment 784 systems: performance of waste stabilization ponds and constructed wetlands. Water Sci. 
Technol. 48(2): 97-104.

786 Sweeney, D.G., Nixon, J.B., Cromar, N.J., and Fallowfield, H.J. 2007. Temporal and spatial

787 variations of physical, biological and chemical parameters in a large waste stabilisation pond,

788 and the implications for WSP modelling. Water Sci. Technol. 55(11): 1-9.

789 doi:10.2166/wst.2007.336.

790 Tuncsiper, B., Ayaz, S.C., and Akca, L. 2012. Coliform bacteria removal from septic wastewater

791 in a pilot-scale combined constructed wetland system. Environ. Eng. Manag. J. 11(10): 1873-

$792 \quad 1879$.

793 Tyagi, V.K., Sahoo, B.K., Khursheed, A., Kazmi, A.A., Ahmad, Z., and Chopra, A.K. 2011. Fate

794 of coliforms and pathogenic parasite in four full-scale sewage treatment systems in India.

795 Environ. Monit. Assess. 181: 123-135. doi:10.1007/s10661-010-1818-4.

796 Ulrich, H., Klaus, D., Irmgard, F., Annette, H., Juan, L.P., and Regine, S. 2005. Microbiological

797 in vestigations for sanitary assessment of wastewater treated in constructed wetlands. Water

$798 \quad$ Res. 39(20): 4849-4858.

799 United Nations. 2015. Resolution Adopted by the General Assembly. NY, USA, New York.

800 USEPA, 1983. Process design Manual: Municipal Waste Stabilization Ponds (Report No. EPA

801 625/1-83-015). Cincinnati, Ohio, USA.

802 USEPA, 2011. Principles of Design and Operations of Wastewater Treatment Pond Systems for 803 Plant Operators, Engineers, and Managers. EPA/600/R-11/088, Cincinnati, Ohio, USA.

804 Van Buuren, J.C.L., and Hobma, S. 1991. The faecal coliform removal rate at post treatment of 805 anaerobically pre-treated domestic wastewater. Department of Environt. Tech. Agricultural $806 \quad$ University, Wageningen. Unpublished.

807 Verbyla, M.E., Iriarte, M.M., Guzman, A.M., Coronado, O., Almanza, M., and Mihelcic, J.R. 

2016. Pathogens and fecal indicators in waste stabilization pond systems with direct reuse for

809 irrigation: Fate and transport in water, soil and crops. Sci. Total Environ. 551-552: 429-437.

$810 \quad$ doi: $10.1016 /$ j.scitotenv.2016.01.159.

811 Verbyla, M.E., and Mihelcic, J.R. 2015. A review of virus removal in wastewater treatment pond $812 \quad$ systems. Water Res. 71: 107-24. doi:10.1016/j.watres.2014.12.031.

813 Wallace, J., Champagne, P., and Hall, G. 2016. Multivariate statistical analysis of water 814 chemistry conditions in three wastewater stabilization ponds with algae blooms and $\mathrm{pH}$ 815 fluctuation. Water Res. 96: 155-165. doi:10.1016/j.watres.2016.03.046.

816 WHO (World Health Organization) 1989. Health guidelines for the use of wastewater in 817 agriculture and aquaculture. WHO Technical Report Series, No.778. World Health 818 Organization, Geneva, Switzerland.

819 Wigginton, K.R., Menin, L., Montoya, J.P., and Kohn, T. 2010. Oxidation of virus proteins 820 during UV254 and singlet oxygen mediated inactivation. Environ. Sci. Technol. 44: 5437821 5443. doi:10.1021/es100435a.

822 Winward, G.P., Avery, L.M., Frazer-Williams, R., Pidou, M., Jeffrey, P., Stephenson, T., and 823 Jefferson, B. 2008. A study of the microbial quality of grey water and an evaluation of 824 treatment technologies for reuse. Ecol. Eng. 32(2): 187-197. 825 doi:10.1016/j.ecoleng.2007.11.001.

826 Wu, S., Carvalho, P.N., Muller, J.A., Manoj, V.R., and Dong, R. 2016. Sanitation in constructed 827 wetlands: A review on the removal of human pathogens and fecal indicators. Sci. Total 828 Environ. 541: 8-22. doi: 10.1016/j.scitotenv.2015.09.047.

829 Zanotelli, C.T., Medri, W., Belli Filho, P., Perdomo, C.C., Mullinari, M.R., and Costa, R.H.R. 830 2002. Performance of a baffled facultative pond treating piggery wastes. Water Sci. Technol. 
$831 \quad \mathbf{4 5}(1): 49-53$

832 Figure 1: Natural disinfection mechanisms in wastewater stabilization ponds (modified from The 833 Global Water Pathogen Project, 2018).

834 Figure 2: Factors influencing sunlight-mediated disinfection.

835 Figure 3: Algal photosynthesis influences on increases in $\mathrm{pH}$ and DO. 
Table 1. Summary of removal of bacteria, viruses, protozoa and helminthes from full/pilot scale WSPs in Africa.

\begin{tabular}{|c|c|c|c|c|c|c|c|}
\hline Country & Reference & $\begin{array}{l}\text { Retention } \\
\text { time (d) }\end{array}$ & Scale & Removal bacteria (log) & Removal viruses (\%) & Removal protozoa (\%) & $\begin{array}{c}\text { Removal helminth eggs } \\
\text { (\%) }\end{array}$ \\
\hline $\begin{array}{l}\text { Burkina } \\
\text { Faso }\end{array}$ & Konate et al., 2013 & 18 & Full scale & & & $\begin{array}{c}>99.99 \text { (Entamoeba } \\
\text { coli, Entamoeba } \\
\text { histolyca, and Giardia } \\
\text { lamblia) }\end{array}$ & $\begin{array}{c}>99.99 \text { (Ascaris } \\
\text { lumbricoldes, Ancylostoma } \\
\text { sp., Trichuris trichiura, and } \\
\text { Trichostrongylus sp.) }\end{array}$ \\
\hline & & & & $\begin{array}{c}6(\mathrm{TC}) \\
4.6(\mathrm{FC}) \\
3.8(\text { E. coli) }\end{array}$ & 79.98 (Coliphage) & & \\
\hline Egypt & El-Deeb et al., 2008 & No data & Full scale & $\begin{array}{c}4.9 \text { (FS) } \\
3.9 \text { (Salmonellae) } \\
2.1 \text { (Listeria) }\end{array}$ & $\begin{array}{c}99.66 \text { (Infectious } \\
\text { rotaviruses) }\end{array}$ & & \\
\hline
\end{tabular}




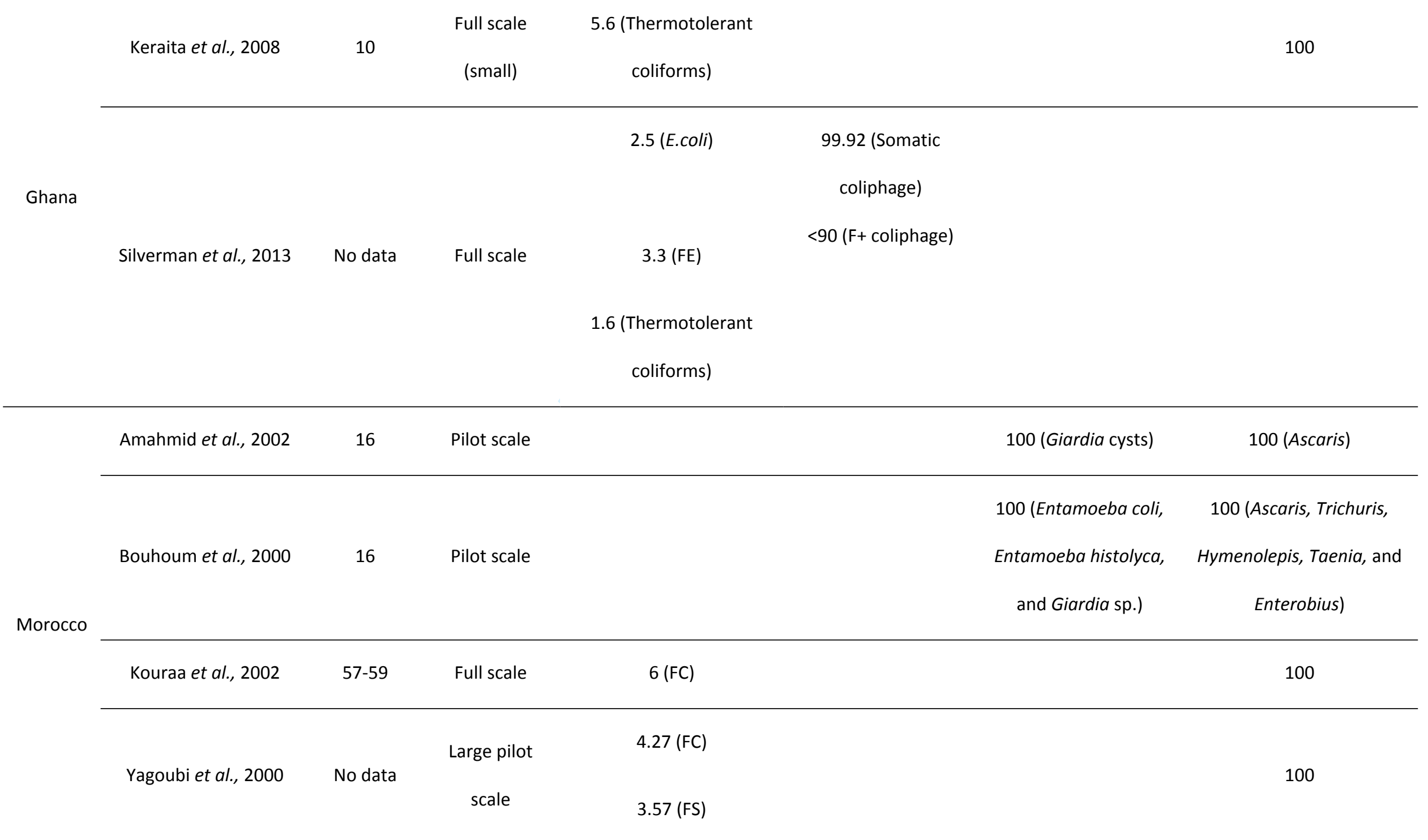


1.18-2 (E. coli)

Ouali et al, 2012

7.94-8.51

Full scale

1.47-2.14 (Enterococci)

Tunisia

\begin{tabular}{llll}
\hline & & & \\
& & \\
Oualietal. 2014 (E. coli)
\end{tabular}

Ouali et al., 2014

7.94

Full scale

$1.5-2.6$ (FS) 
Table 1. Summary of removal of bacteria, viruses, protozoa and helminthes from full/pilot scale WSPs in Americas.

\begin{tabular}{|c|c|c|c|c|c|}
\hline Country & Reference & $\begin{array}{l}\text { Retention } \\
\text { time (d) }\end{array}$ & Scale & Removal bacteria (log) & Removal viruses (\%) \\
\hline \multirow{4}{*}{ Bolivia } & Hadley, 2013 & 24 & Full scale & & 91 (Somatic coliphage) \\
\hline & & & & & 99.92 (Culturable enteroviruses) \\
\hline & Symonds et al., 2014 & 25.5 & Full scale & & 99.97 (Norovirus GI) \\
\hline & & & & & 99.94 (Rotavirus Group A) \\
\hline \multirow{8}{*}{ Brazil } & Dias et al., 2014 & $4.8-14.5$ & Full scale & 4.4-5.4 (E. coli) & \\
\hline & Pivelli et al., 2008 & 20 & Full scale & $2.58(\mathrm{TC})$ & \\
\hline & riveill el un., 2000 & 20 & ruil scale & 2.89 (E. coli) & \\
\hline & Von Sperling et al., 2002 & 6.3 & Full scale & 1.64 (E. coli) & \\
\hline & Von Sperling et al., 2003 & $6.1-9.3$ & Full scale & & \\
\hline & $\begin{array}{l}\text { Von Sperling and } \\
\text { Mascarenhas, } 2005\end{array}$ & 7.4 & Full scale & 5.1 (E. coli) & \\
\hline & Zanotelli et al., 2002 & 124.3 & Full scale & $5(\mathrm{FC})$ & \\
\hline & & & & $7(\mathrm{TC})$ & \\
\hline \multirow{3}{*}{ Canada } & & & & 3.2-5.5 (Thermotolerant coliforms) & 0-99.84 (Somatic coliphage) \\
\hline & Locas et al., 2010 & $16.2-19.6$ & Full scale & 2.8-5.1 (FE) & $\begin{array}{c}\text { 80-99.984 (Male-specific } \\
\text { coliphages) }\end{array}$ \\
\hline & & & & $0.8-2.3(\mathrm{CL})$ & $\begin{array}{c}-25.9-90 \text { (Human enteric } \\
\text { viruses) }\end{array}$ \\
\hline Chile & Herrera and Castillo, 2000 & 5.3-7.6 & Full scale & $1.48-1.86(\mathrm{FC})$ & \\
\hline
\end{tabular}




\begin{tabular}{|c|c|c|c|c|c|}
\hline \multirow{7}{*}{ Colombia } & \multirow{4}{*}{ Campos et al., 2002} & \multirow{4}{*}{53} & \multirow{4}{*}{ Full scale } & $3.1-3.5(\mathrm{FC})$ & $\begin{array}{c}\text { 99.21-99.97 ( } \mathrm{F}+\text { phages } \\
\text { Bacterial fragilis) }\end{array}$ \\
\hline & & & & 3-4.4 (E. coli) & \\
\hline & & & & 3-3.9 (FS*) & 93.69-99.997 (Somatic phages) \\
\hline & & & & $3.3(\mathrm{CL})$ & 87.41 (RYC phages) \\
\hline & \multirow[b]{2}{*}{ Madera et al., 2002} & \multirow[b]{2}{*}{12} & \multirow[b]{2}{*}{ Full scale } & $4(\mathrm{FC})$ & \\
\hline & & & & 1.7 (FS) & \\
\hline & Vorkas and Lloyd, 2000 & 7.98 & Full scale & $1.5(\mathrm{FC})$ & \\
\hline \multirow{2}{*}{ Honduras } & \multirow{2}{*}{ Oakley, 2005} & \multirow{2}{*}{$7.2-34.8$} & \multirow{2}{*}{ Full scale } & 2.97 (E. coli) & \\
\hline & & & & $2.93(\mathrm{FC})$ & \\
\hline Mexico & Escalante et al., 2000 & 945 & Full scale & $3.7(\mathrm{FC})$ & \\
\hline Nicaragua & Buchauer et al., 2007 & 16 & Full scale & $0.54-4(\mathrm{FC})$ & \\
\hline
\end{tabular}


Table 3. Summary of removal of bacteria, viruses, protozoa and helminthes from full/pilot scale WSPs in Asia.

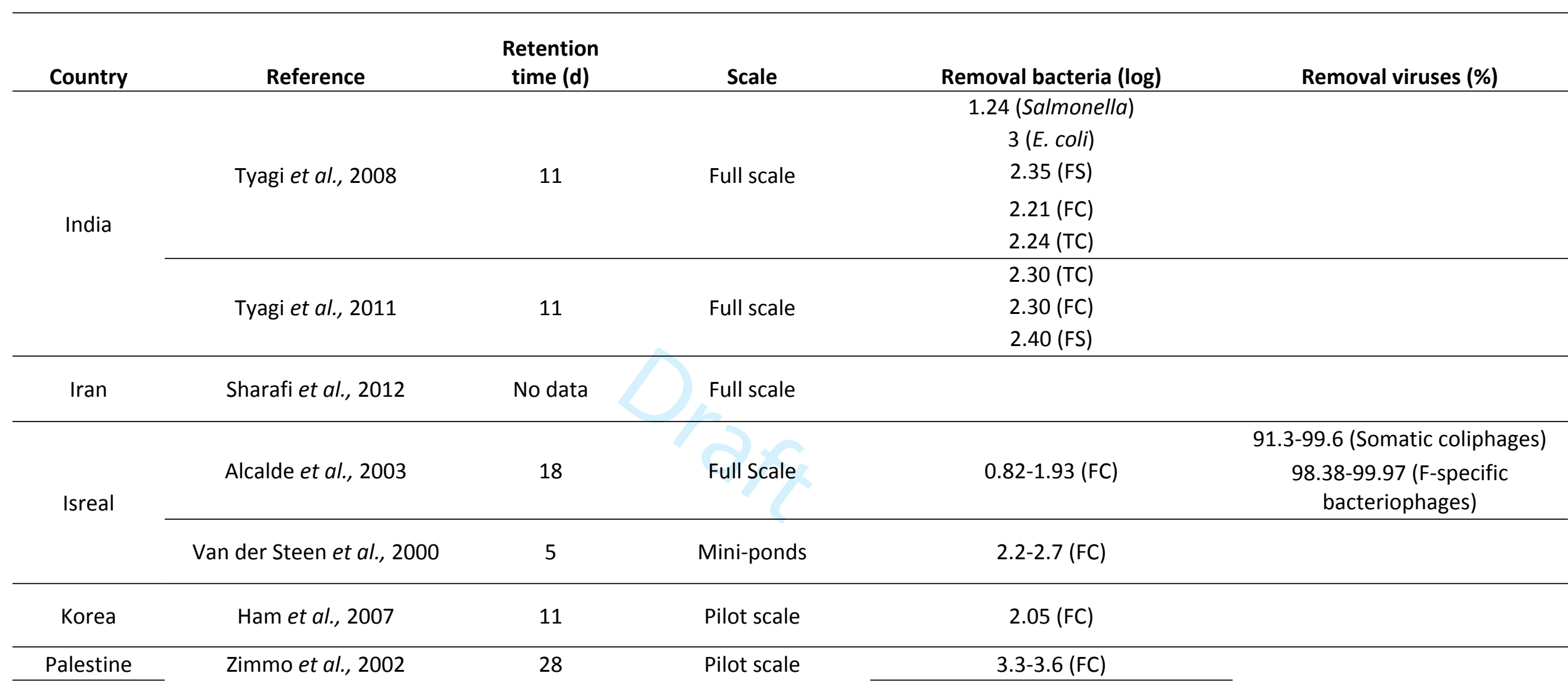


Table 4. Summary of removal of bacteria, viruses, protozoa and helminthes from full scale WSPs in Europe.

\begin{tabular}{|c|c|c|c|c|c|}
\hline \multirow{4}{*}{ Belgium } & \multirow{4}{*}{ Nameche et al., 2000} & \multirow{4}{*}{7} & \multirow{4}{*}{ Full scale } & 3.40 (TC) & \\
\hline & & & & $2.62(\mathrm{FC})$ & \\
\hline & & & & 3.64 (FS) & \\
\hline & & & & $\begin{array}{c}1.88 \text { (Sulphite-reducing } \\
\text { Clostridium) }\end{array}$ & \\
\hline \multirow{5}{*}{ France } & Brissaud et al., 2000 & $2.0-3.0$ & Full scale & $1.7(\mathrm{FC})$ & \\
\hline & \multirow{2}{*}{ Da Silva et al., 2008} & \multirow{2}{*}{ Several weeks } & \multirow{2}{*}{ Full scale } & & 98.42 (Norovirus GI) \\
\hline & & & & & 97.49 (Norovirus GII) \\
\hline & \multirow{2}{*}{ Picot et al., 2005} & \multirow{2}{*}{95} & \multirow{2}{*}{ Full scale } & $4.1(\mathrm{FC})$ & \\
\hline & & & & 3.4 (FE) & \\
\hline \multirow{3}{*}{ Greece } & \multirow{2}{*}{ Parissopoulos et al., 2003} & \multirow{2}{*}{$35-106$} & \multirow{2}{*}{ Full scale } & $1.68-4(\mathrm{TC})$ & \\
\hline & & & & $1.73-4(\mathrm{FC})$ & \\
\hline & \multirow{2}{*}{ Gratziou and Chalatsi, 2013} & \multirow{2}{*}{ No data } & \multirow{2}{*}{ Full Scale } & 2.7- 4 (FC) & \\
\hline \multirow{15}{*}{ Spain } & & & & $1.3(\mathrm{TC})$ & \\
\hline & Amengual-Morro et al., 2012 & 69 & Full scale & $4(\mathrm{FC})$ & \\
\hline & \multirow{5}{*}{ Gomila et al., 2008} & \multirow{5}{*}{60} & \multirow{5}{*}{ Full scale } & $1.26(\mathrm{TC})$ & 97.2 (SOMPCPH) \\
\hline & & & & $1.28(\mathrm{FC})$ & 95.8 (F-specific phages) \\
\hline & & & & 0.86 (E. coli) & 73.8 (Enteric viruses) \\
\hline & & & & $0.54(\mathrm{FE})$ & 87.2 (BFRYCPH) \\
\hline & & & & 1.25 (Clostridium spp.) & $\begin{array}{c}83.3 \text { (Phages of B. } \\
\text { thetaiotamicron GA17) }\end{array}$ \\
\hline & \multirow{3}{*}{ Lucena et al., 2004} & \multirow{3}{*}{49} & \multirow{3}{*}{ Full scale } & $2.5-4.7(\mathrm{FC})$ & 93.69-96.02 (BFBRYCPH) \\
\hline & & & & 2.5-2.7 (FE) & 99.87-99.99 (SOMCPH) \\
\hline & & & & 1.3-1.4 (SRC) & 99.37-99.95 (FRNAPH) \\
\hline & \multirow{5}{*}{ Mosteo et al., 2013} & \multirow{4}{*}{50} & \multirow{4}{*}{ Full scale } & 1.38 (E. coli) & \\
\hline & & & & 5.51 (Enterococcus spp.) & \\
\hline & & & & 1.78 (Staphylococcus aureus) & \\
\hline & & & & 0.51 (Pseudomonas sp) & \\
\hline & & 24 & Full scale & 2.14 (E. coli) & \\
\hline
\end{tabular}


3.61 (Enterococcus spp.)

0.05 (Pseudomonas sp)

$0.7(\mathrm{CL})$

2.5-2.8 (TC)

3-5 (E. coli)

3-3.9 (FS)

96-99.8 (Coliphage)

Reinoso et al., 2011

5.5

Full scale

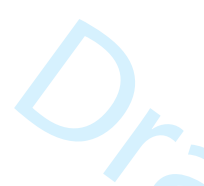

https://mc06.manuscriptcentral.com/er-pubs 


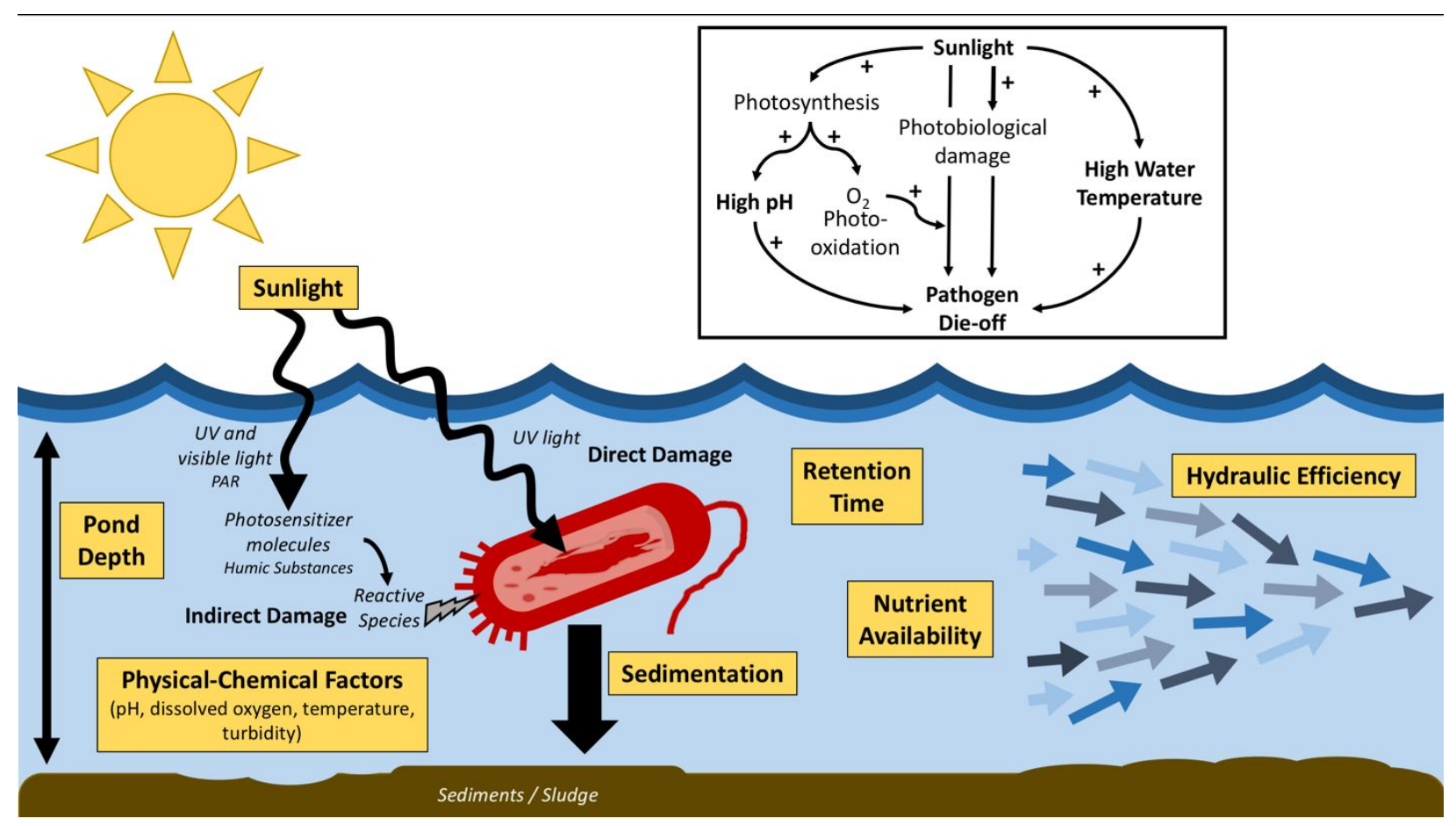

Figure 1. Natural disinfection mechanisms in wastewater stabilization ponds (modified

from The Global Water Pathogen Project, 2018). 


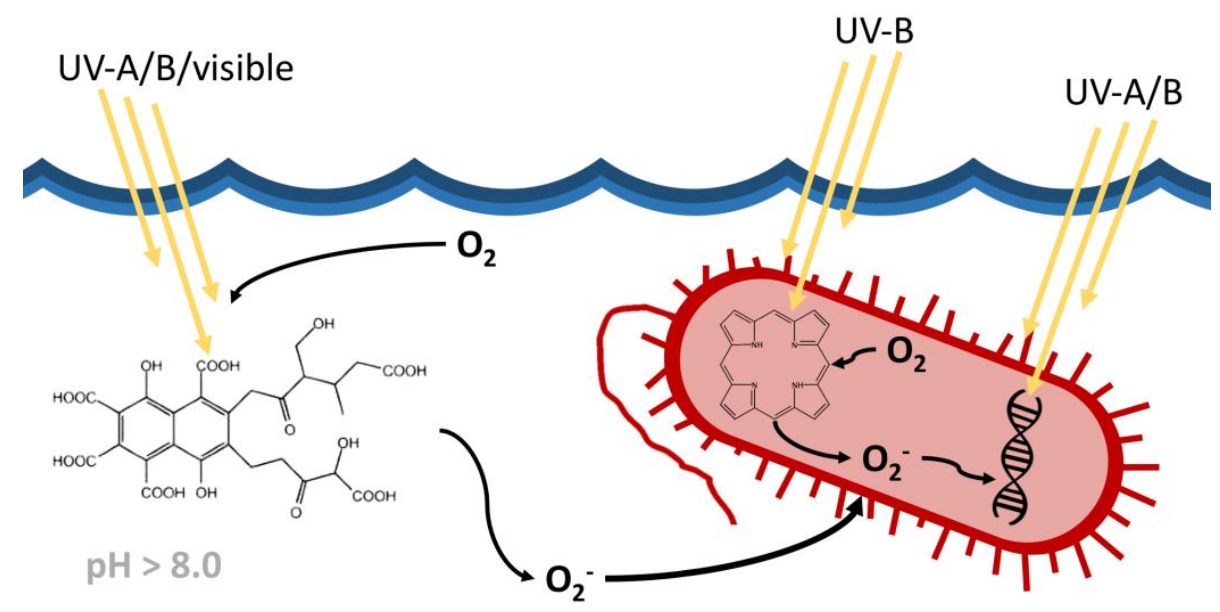

Figure 2. Factors influencing sunlight-mediated disinfection. 


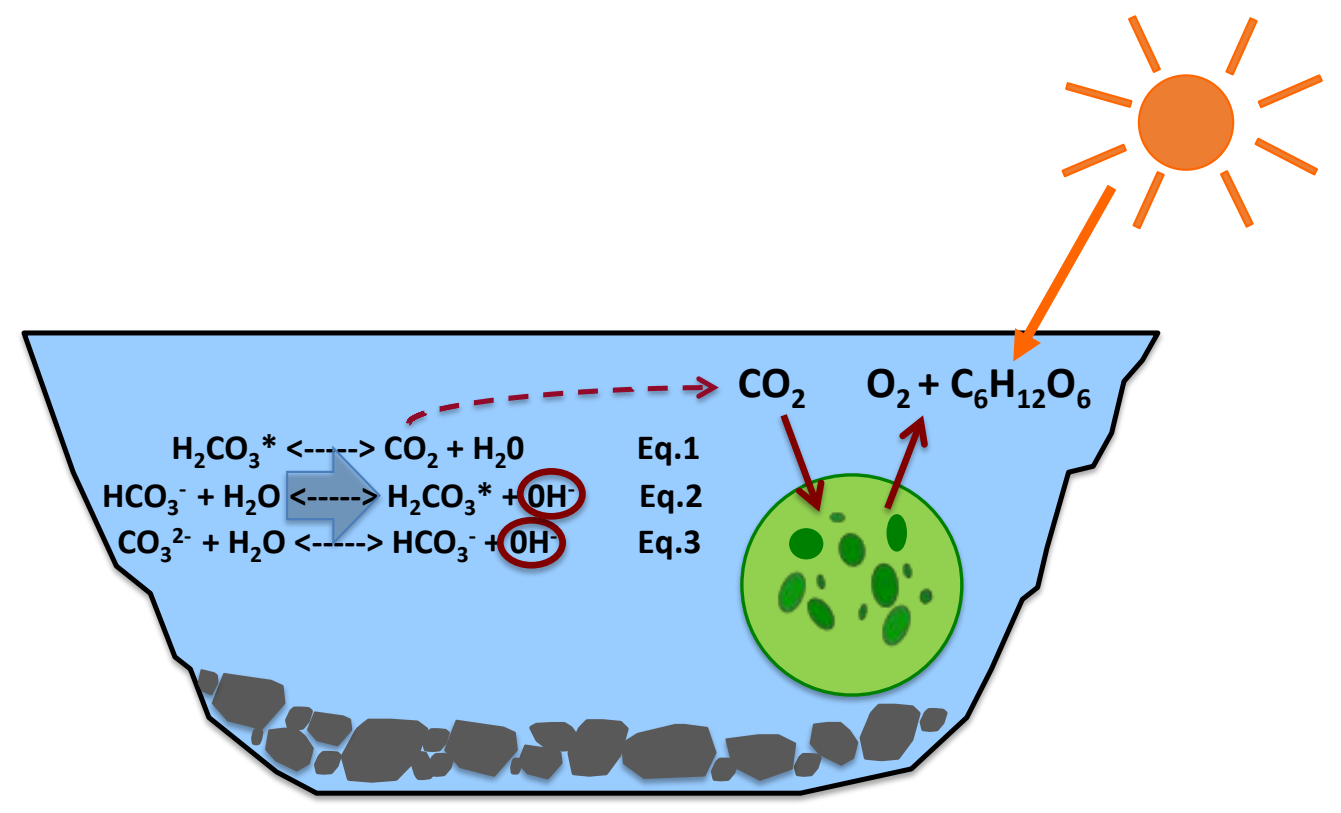

Figure 3. Algal photosynthesis influences on increases in pH and DO. 